\title{
Tyrosine Kinase Inhibitor
}

National Cancer Institute

\section{Source}

National Cancer Institute. Tyrosine Kinase Inhibitor. NCI Thesaurus. Code C1967.

Any substance that inhibits tyrosine kinase, an enzyme involved in the transduction and processing of many extracellular and intracellular signals including cell proliferation.

Inhibition of tyrosine kinase may result in inhibition of cell growth and cell proliferation. 